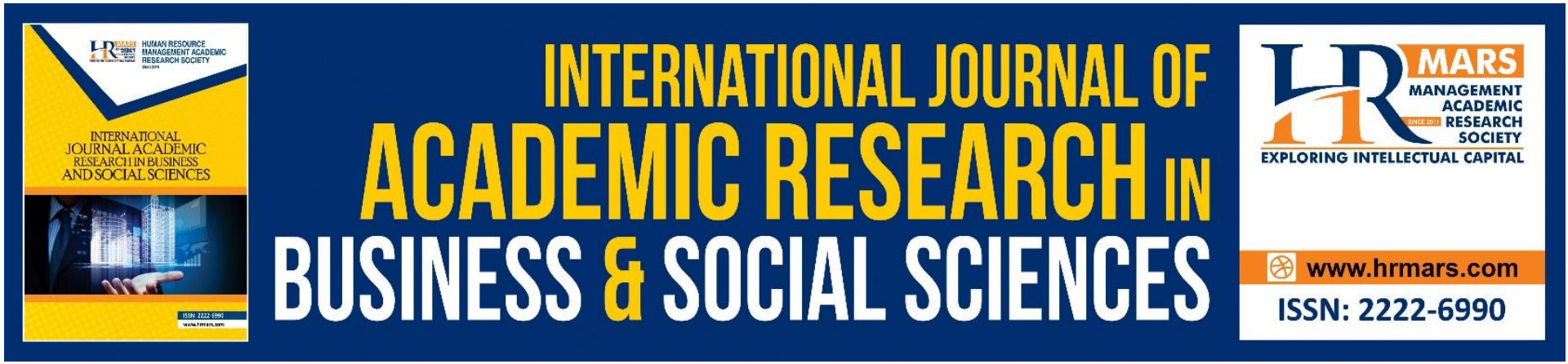

\title{
Formation of the Integration Platform through the Historical Trajectory of Governance in Malaysia
}

\author{
Nurshuhada Mohamed, Mansor Mohd Noor \& Nor Azlili Hassan
}

To Link this Article: http://dx.doi.org/10.6007/IJARBSS/v11-i11/11554 DOI:10.6007/IJARBSS/v11-i11/11554

Received: 10 September 2021, Revised: 12 October 2021, Accepted: 22 October 2021

Published Online: 04 November 2021

In-Text Citation: (Mohamed et al., 2021)

To Cite this Article: Mohamed, N., Noor, M. M., \& Hassan, N. A. (2021). Formation of the Integration Platform through the Historical Trajectory of Governance in Malaysia. International Journal of Academic Research in Business and Social Sciences, 11(11), $550-560$.

Copyright: @ 2021 The Author(s)

Published by Human Resource Management Academic Research Society (www.hrmars.com)

This article is published under the Creative Commons Attribution (CC BY 4.0) license. Anyone may reproduce, distribute, translate and create derivative works of this article (for both commercial and non-commercial purposes), subject to full attribution to the original publication and authors. The full terms of this license may be seen at: http://creativecommons.org/licences/by/4.0/legalcode

Vol. 11, No. 11, 2021, Pg. $550-560$

Full Terms \& Conditions of access and use can be found at http://hrmars.com/index.php/pages/detail/publication-ethics 


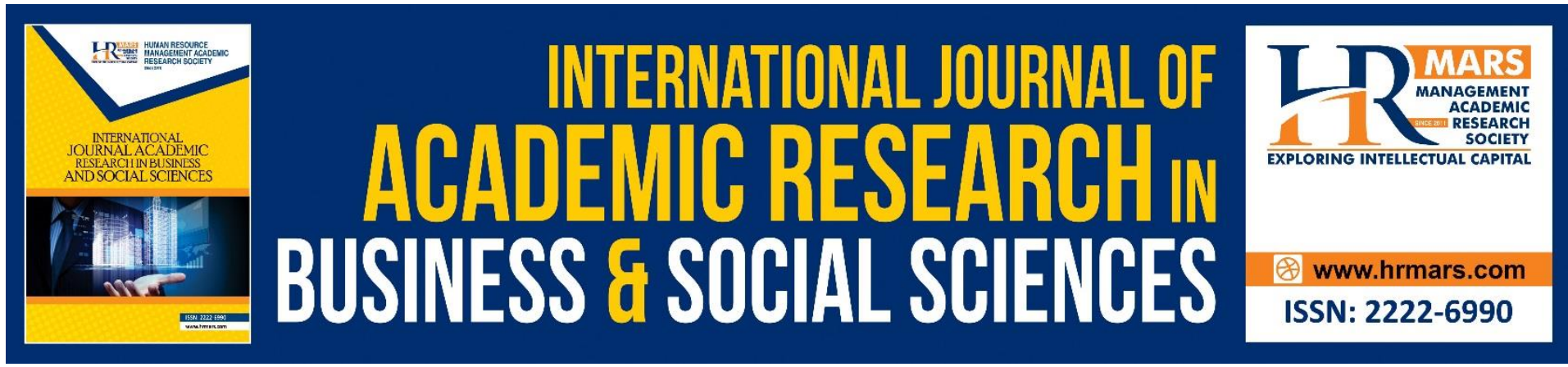

\title{
Formation of the Integration Platform through the Historical Trajectory of Governance in Malaysia
}

\author{
Nurshuhada Mohamed ${ }^{1}$, Mansor Mohd Noor ${ }^{2} \&$ Nor Azlili \\ Hassan $^{3}$ \\ ${ }^{1}$ Senior Lecturer at Center for Fundamental Studies, UNISZA, ${ }^{2}$ Fellow Academic at Institute \\ of Ethnic Studies, UKM, ${ }^{3}$ Assistant Professor at Department of General Studies, Faculty of \\ Creative Industries, UTAR. \\ Email: shuhadamohamed@unisza.edu.my,mnmansor@ukm.edu.my, azlili@utar.edu.my
}

\begin{abstract}
The formation of the platform of integration or unity in a country and society has undergone a long process and period. This long process and periods can be seen through the historical trajectory that has been passed by a country. The platform of integration was formed due to racial conflict. Two methods were used to resolve the racial conflicts, whether military or bargaining methods, negotiation and mediation. The history of Malaysia has acknowledged that bargaining, negotiation and mediation (BNM) methods were adopted by the British as an administrator in Malaya before independence day. The methods have formed the integration in the governing system and the unity of ethnic relations in Malaysia till today. Throughout the process of forming governance, there are certainly challenges and conflicts as Malaysia is known as a multi-ethnic nation since the colonial era. The cooperation of all ethnic groups has been formed for the sake of independence by forming a new government. This ethnic collaboration demands the establishment of a committee to coordinate, organize and find a consensus, thoughts and views between the ethnic representation within the country. The purpose of this study is to understand how the platform of integration through unity was formed through committees that were set up in the colonial era in 1948, which is known as the Communities Liaison Committees (CLC). The CLC was used as the focus of this study to understand how the principles and bases of integration were established. The establishment influenced the formation of other committees after the post-colonial era. It acts as a platform of integration when there is a racial conflict. Content analysis was implemented to analyze and codify the meanings in CLC documents between the years 1948 and 1952. Annales School's approach was applied as an analytical tool to examine the political, economic and social issues through the role of CLC. This study proves that the CLC provides a platform of integration for building a nation through a multi-ethnic unity in Malaysia.
\end{abstract}

Keywords: Integration, Governance, Social Unity Element, Annales School. 


\section{Introduction}

The formation of an integration platform in a multi-ethnic country requires periods and a long process. The level of integration in a country is measured through the history of the formation of a governing body for that country. The process of forming the government is closely related to the social change theory in line with modernization which was popularized by the west. Malaysia's historical trajectory explains the process of forming a platform of integration based on the process of forming governance or known as the process of nation-building in the era of colonialism.

The history of the formation of nation-building in each country has different trajectories and platforms. For instance, the Indonesian state of Dutch colonialism, produced a platform of assimilation through one country one nation, while Malaysia due to British colonialism, produced a platform of integration through one country embedded with Malay Civilization. This constitutes Malaysia's identity and nation (which is still in the process of construction) of Malaysians today. The acceptance of diversity has opened opportunities and spaces for society to understand the different cultures and religions. The dynamism of this culture is described by Robert E. Park (1898) that applies in the process of structural change in society. Cultures include segregation, accommodation, assimilation, amalgamation and integration. This form of relationship was born from the process of nation-building for each country. Some countries like Malaysia experienced the form of segregation relationships at the beginning and move towards accommodation and integration.

According to Shamsul (2018), the integration base can be divided into three categories according to historical trajectory. The first category was the violence conflict era (1944-1969) that took place during the colonial and post-colonial era; the second category was the stable tension era (1970-2001) after the implementation of the New Economic Policy (NEP), and the third category was the social cohesion era (2001 to present). The historical choice is not an option that we can decide today. But the result of this historical choice has shaped and built the country as well as colored the society and culture in Malaysia today. The implications of this historical choice need to be analyzed to examine the picture of the nation-building process. Certainly, this option is the effort and role of the actors alongside the institutions created during the colonial and post-colonial era. This paper focuses on the Communities Liaison Committees (CLC) which was established during the colonial era.

The body which is known as CLC was established in 1948. The function of establishing this committee is to act as a body of seeking mutual understanding and cooperation between the ethnics, and eventually, builds a formula of integration. Integration in the CLC was born from the role of the committee in managing the issues of diversity among the various societies and ethnicities. Therefore, the CLC is one of the platforms that is consciously established to achieve the cohesion that finally produces the integration of cultures in the colonial era. The methods applied in the process of achieving this integration of cultures include Bargaining, Negotiation and Mediation. These three methods are social cohesion elements to achieve the integration of multi-ethnic communities.

\section{Scope and Methodology}

This research employs a sociological macro study that examines the process of forming a platform of integration through the establishment of governance. The research applies the 
Annales School method such as the Historical Trajectory as an analytical tool to understand the formation of a platform of integration in Malaysia through the involvement of all ethnicities. Therefore, the choice of social change theory is functionally significant in characterizing and categorizing changes of the state and society in the colonial era. An eclectic approach is implemented in this research due to more than two theories and concepts used. The archive documents are chosen as data collection because the affected heads of each ethnic were passed away. This qualitative research approach will focus on archival research by referring to data such as meeting minutes, personal documents and correspondence letters from the year of 1948 to 1952.

\section{Concept and Theory}

The concept of democratic consensus coincides with a country that covered a diverse and complex ethnicity. This model is a practice for the countries that are leading towards independence and building a modern country. For this study, the CLC is seen as a model that applies the characteristics of consociationalism and social cohesion elements throughout the process of inter-ethnic cooperation that eventually forms the platform of integration. Five characteristics of consociationalism applied in the CLC as described by Lijphart (1970; 1999), including the role of heads of ethnic, negotiation, bargaining, mediation and the establishment of institutions. However, for this paper, the element of cohesion is only focused on three characteristics, namely bargaining, negotiation and mediation.

The element of the cohesive negotiation was explained by Bailey (1969) that this method of negotiation needs to be conducted through a face-to-face meeting. This method is also known as face to face hypothesis which emphasizes the social ties that are measured through the collectivity of society. For example, a face-to-face meeting is a kind of action that can narrow the gap in the socialization process through the interaction between ethnicities. Through this method, bargaining and negotiation processes focus on the issues and agenda being discussed. Issues and agendas are divided into two, namely, the value of collective and value of conflict that existed throughout the discussion process before the consensus being achieved.

The value of collective refers to the value of unity. Bailey (1969: 6) describes it as the phrase values of unity that resembles ideas about consensus and it is a mystique about the collectivity. McAdam (2011) explains that this collective action is human behavior that involving two or more individuals as a result of encouragement and the desire to change some aspects of social life or against the changes proposed by the others. Whereas the value of conflict refers to a conflict perspective that occurs in a multi-racial society. It is a difference of opinion resulting from the belief that it holds. Consequently, elements of cohesion such as bargaining and negotiation are important in this process to provide a space and opportunity for all parties involved.

Mediation is then discussed by Saravanamuttu (2016: 10) as a process that enables to fulfill the ethnic, religious and cultural demands as well as guides its actors towards a win-win situation or the number of consequences changing rather than zero. He also explained that the mediation process in Malaysia incorporating consociationalism with other ethnic groups towards a social policy is a strategy for success, especially in elections. Mediation in sociology refers to the techniques used to solve conflicts and is represented by the trained and 
recognized intermediaries (Wan \& Wan 2008: 216). These three elements are intended to achieve consensus either within the community, society or country. The element which is known as the social cohesion element is a tool for achieving racial integration in the nationbuilding (still in process) of Malaysia.

The integration base which is described by Shamsul (2018), or in this study introduces it as a platform, is a social and physical space. Social space means a space that is looking for a consensus and different point of view, thoughts and position that created through Bargaining, Negotiation and Mediation. Among BNM's features are the network and collaboration; the physical symbolic manifestations such as the national monument; and permanent or fragile. The explanation given by Shamsul $A B$ about this third feature stated that if the social space is permanent, then the result will be long-lasting and vice versa.

The debate on the concept of governance in this study refers to the management of political development. The term governance in the sociological perspective discusses the use of a network or system theory. Based on the previous studies, the concept of governance is meant to change and transform. Governance signifies a change in the meaning of government, referring to a new process of governing; or changed conditions of ordered rule; or new methods by which society is governed (Rhodes, 1996: 521). Governance also requires consensus as a mechanism for change, transition and transformation. The literature review in the governance perspective is divided into four definitions, structures, processes, mechanisms and strategies (Faur, 2012: 555).

All scholars who studied in this field agreed that history was an important element to know the form and pattern of government. Risse (2011: 41) proposes two characteristics of colonial rule and administration. Firstly, undertaking roles in the process and negotiations in the early stages of the establishment of modern countries. In the event of violent conflict, the proposed settlement method is negotiation and legislation. Similar methods were also practiced by the British during the conflict in the Malay kingdoms. The method of negotiations and legislation were also adopted during the establishment of the 1946 Malayan Union, the 1948 Malaya Federation as well as the CLC at the end of 1948 and Malaya 1957. The transformation and transition of this form of government were formed when there were internal conflicts and external influence.

Secondly, the concept of governance is tied to historical sources that constantly narrate the historical conflicts of power delegations towards actors or agencies. Historical dimensions play an important role in assessing and viewing the change of today's governance. Among the criteria that we can consider is the origin of government, ethnic divisions and legal system in a country like Malaysia today. This study examines the forms and characteristics of government brought by the British into Malaya, that lead to changes in the structure of the society and the country in a more complex and organized manner, which finally drafted a constitution to regulate and manage the communities and the country.

\section{Discussion}

The level of unity model as described in Table 1.0 is a group of ethnicity studies conducted by Shamsul $A B$ and Mansor Mohd Noor which was then adopted by the researcher. This level of unity model explains the level of relationship that has been passed by Malaysia since the pre- 
colonial era (before 1874), colonial-era (1874-1957) and post-colonial era (after 1957). The process of building these levels of unity is seen from the historical trajectory. The analytical tool which is applied to measure this level of unity is employing the Annales School method. This tool considers all aspects of social, economic and political issues that comprising ethnic issues within Malaysia.

Based on Table 1.0, there are seven levels of unity in multi-ethnic society in Malaysia throughout the country and nation-building process till today. The level of unity is based on the phenomenon and the issues raised by the ethnics. Conflict and segregation levels describe the condition that occurred before independence. The issue of struggling for the throne, occupation and competition between the guest community and the immigrant community created a lot of conflicts. It also caused a riot and thus, the social relationship also did not work well which then led to the collapse of the golden age of the Malay Sultanate. This segregation can be seen during the implementation of the British Divide and Rule policy in Malaya society. This relationship caused tension and riots as the life of the community was managed by the British in a segregated and isolated manner with some ethnicities met each other only for economic activity purposes.

This level of segregation has a modest tie that is not good but reunited within the framework of the British administration. This meeting of segregated communities was tied to the establishment of the CLC. CLC creates the dimensions of value in acknowledging and respecting each other throughout its establishment. The form of accommodation relationship indirectly exists during the establishment of the economic and political development framework in Malaya. There is no denying that inter-racial disputes and conflicts existed but elements of cohesion such as mediation, negotiation and bargaining provide hope for restoring ethnic relationships and building unity in their relations. 
Table 1.0: Level of Unity Model

\begin{tabular}{|c|c|c|c|c|c|}
\hline Level & $\begin{array}{l}\text { Dimension } \\
\text { of Value }\end{array}$ & Issue & $\begin{array}{l}\text { Social } \\
\text { Relationship } \\
\text { Form }\end{array}$ & Result & IKKN \\
\hline Conflict & Collapse & Politic & $\begin{array}{l}\text { Social } \\
\text { Dysfunctional }\end{array}$ & Riot Risk & Very bad \\
\hline Segregated & Recognizing & $\begin{array}{l}\text { Centralized } \\
\text { Political State/ } \\
\text { Federalism } \\
\text { Social class }\end{array}$ & $\begin{array}{l}\text { Pluralism (plural } \\
\text { segregation) }\end{array}$ & $\begin{array}{l}\text { Segregated } \\
\text { strain \& } \\
\text { isolated } \\
\text { fights } \\
\text { Integration } \\
\text { Hot spot }\end{array}$ & $\begin{array}{l}\text { Moderately } \\
\text { bad }\end{array}$ \\
\hline Contrast & Respect & $\begin{array}{l}\text { Centralized } \\
\text { Political State/ } \\
\text { Federalism } \\
\text { Development } \\
\text { Education } \\
\text { Language } \\
\text { Interaction \& } \\
\text { Space } \\
\text { Social Class } \\
\text { Ethnic Group } \\
\text { Ethnicity }\end{array}$ & Accommodation & $\begin{array}{l}\text { (Agree to } \\
\text { disagree) }\end{array}$ & Less bad \\
\hline Tolerance & Acceptance & $\begin{array}{l}\text { 1. Political } \\
\text { Alliance } \\
\text { 2. } \\
\text { Development } \\
\text { 3. Language } \\
\text { 4. Education } \\
\text { 5. Ethnicity }\end{array}$ & Enculturation & Social links & Less good \\
\hline \multirow[t]{2}{*}{$\begin{array}{l}\text { Gathering } \\
\text { / Meeting }\end{array}$} & $\begin{array}{l}\text { Shared } \\
\text { same value } \\
\text { Celebrating } \\
\text { unity in } \\
\text { diversity }\end{array}$ & $\begin{array}{l}\text { 1. Ethnicity } \\
\text { 2. Politic } \\
\text { 3. Religion }\end{array}$ & $\begin{array}{l}\text { Segmented } \\
\text { Assimilation }\end{array}$ & Social Ties & $\begin{array}{l}\text { Moderately } \\
\text { good }\end{array}$ \\
\hline & & & Amalgamation & $\begin{array}{l}\text { Social } \\
\text { Attachment }\end{array}$ & Good \\
\hline Consensus & $\begin{array}{l}\text { Towards } \\
\text { Unity }\end{array}$ & 1. Election & Integration & $\begin{array}{l}\text { Moments } \\
\text { of Unity }\end{array}$ & Very good \\
\hline
\end{tabular}

Sources: Shamsul et al. (2018: 171)

Events of violent conflicts in the issue of ethnicity as happened in 1969 had a profound consequence on the Malays and Chinese community. It is also known as a violent bloody 
conflict that leads to an emergency declaration. If referring to Table 1.0, this event can be categorized at the opposite level. This is due to the value of respect each other but still exist hot spot result in some economic and political issues. Shamsul (2008; 2012a; 2012b; 2014) described this conflict as agree to disagree because it is still in the early stages of forming accommodation. The ties between societies at this stage are considered to be low and not good as it affected the socio-political stability.

Resulting of this riot, the government has given the mandate to the National Movement Council (MAGERAN) to solve this problem. MAGERAN was established in 1969 and formed the National Unity Council (1969-1971) to address the racial riots on May 13, 1969. It was represented by various ethnicities representing the people in Malaysia. The modus operandi of the establishment of MAGERAN was similar to the establishment of the CLC in 1948, where it sought solutions to build unity among various ethnicities. The discussions held in the MAGERAN committees had a major impact on the unity among ethnics through the establishment and implementation of the New Economic Policy (1970). This policy provides space and opportunity to improve the economic conditions for all ethnicities to avoid any imbalance in economic activity.

The National Unity Council was disbanded simultaneously with the dissolution of MAGERAN due to the revival of the governmental parliamentary democracy on 23 February 1971 (JPNIN 2016). In this regard, the National Unity Advisory Council replaced this council to address issues which are related to racial unity in Malaysia. It is represented by 51 members of various ethnicities and maintains the role of the National Unity Council. As of January 1, 1972, the Ministry of National Unity has been established and served as a secretariat to the council chaired by the Honorable Minister of National Unity (Y.B.).

The establishment of the National Unity Consultative Council (NUCC) on September 15, 2011, is a body that serves as a mechanism of unity by applying the concept of national unity. This establishment is due to the emergence of racial polarization after the 13th election through observation. Before this situation, an incident occurred which resulted in the rise of Indian protests. The racial polarization issue occurred when HINDRAFF appeared to demand a charge on British action against the Indians before independence. It was represented by 30 Hindus from various NGOs who sent a memorandum to Britain to seek damages for taking the Indians as low labor. NUCC's representative council is also represented by all religious leaders of various ethnicities in Malaysia. Discussions and criticisms in this committee gave an exposure to other religions to understand the other religious practices.

The clarification on religious practices as stated in the Islamic constitution, namely Article 3, refers to the Religion of Islam as the Federal Religion and the Official Religion for the Malaysian government. However, it also recognizes other religions to be practiced as long as it does not conflict and contradict with the constitution. This level is categorized as a gathering and meeting stage as it has been able to share the shared values resulting from social engagement and ties in community life. This form of relationship is categorized as segmented assimilation where there has been a process of merger and unification between various ethnic groups. This unification process forms a new group with the same culture and identity. The identity of this group is based on religion to give an understanding of religious differences and practices which does not prevent them from working towards unity. 
The final level namely, consolidation is seen as a new phenomenon for the general election in Malaysia. This level can also reflect on the reality of Malaysia today following the outcome of the $\mathbf{2 0 1 3}$ general election, where racial polarization is divided into two parts. The first part is the total votes won by the opposition parties were dominated by the urban areas in Malaysia such as Selangor and Penang. While the second part is the Barisan Nasional (BN) victory can only maintain its votes in the rural areas. While PAS can still defend its territory in Kelantan. Both conditions where BN's power and the opposition party coalition won in different areas and classes were due to several factors. The factors include the political sources of information, individual economic conditions, political development, issue factors, leadership, political ideology, historical factors as well as sociological factors such as family, age, gender, level of education, income, ethnicity, religion and class (Junaidi et al., 201; 80). For the 14th General Election, another moment of unity emerged when the people democratically voted for a new government to hold and lead the Malaysian government. The form of relations at this level creates an integration that combines multiple ethnicities in culture and forms a unity effectively due to political maturity. The combination comprises youths, intellectuals and upper-class members who want new administrative and governance patterns. This relationship is seen as a moment of unity among the community and the relationship is very good.

\section{Conclusion}

The government or governance framework was deployed and formed by the British. The British functioned as mediation for all communities in Malaya in formulating the formation of the governance. The role of the British is directly driving the committees or institutions such as the CLC, the Alliance Party and the REID Commission to move following their plans. In conclusion, the change that has taken place in Malaysia today is a change that has been arranged by the British consciously based on its colonial knowledge. The system was built as a trigger for the governance transformation in Malaysia during the colonial era. The functions and roles of the governance are examined through the changes in the structure of the society and the state; as well as through the social process that applies the consociationalism instrument and the social cohesion elements of BNM to build a modern country.

The form of development planning as discussed in the CLC is one of the formations of governance platforms which is established by the British. It can be seen when the British recognized the CLC memorandum as a constitution for Malaya independence. CLC also builds a platform of integration in ethnic relations. It is called a platform because there is a conflict but there is always a negotiation as the solution. The negotiations are made to find a shared space in a country. The negotiation method also acts as the solution to fulfill the diverse needs and demands of each community in the country. The governance framework for the Federation of Malaya in 1957 set up the system of the Democratic Parliamentary State and the Constitutional Monarchy. The system is managed and administered through four institutions, namely the Executive, the Legislation, the Judiciary and the Council of the Rulers. The management of a multiracial society is then governed by the formulation of economic and social policy that incorporates the elements of social cohesion to create integration. Faruqi (2015) also recognizes that the features of the Federal Constitution are described as a policy that manages and regulates the life of Malaysians. 
Cultural dimensions born from CLC, are the bases of integration that are applied throughout the CLC discussions. This culture fosters new culture and values for collective decision-making on some of the demands and bargains of both ethnicities. It even creates a shared culture of all ethnicities. Throughout this social process, the values of cooperation, mutual respect and trust among each other constitute the core of racial consensus. It also proves that the value and culture were born of CLC or known as CLC DNA such as the political accommodation which has been practiced in political alliances till today. The opposition also took the same approach when cooperating with other political parties. Certainly, some challenges and conflicts necessarily exist in line with the changing world of globalization and without borders. The debate by Noor (2012) proves that the composition of Malaysians today requires new interpretation and research in nation-building. Shamsul (2014) also acknowledges that nation-building is still underway and becomes a national agenda in the implementation of policies and regulations. However, the model for nation-building should refer to the historical choice that has been implemented in the colonial era. As a result of this election were the birth of the Federal Constitution 1956, the Federation of Malaya 1957, the Formation of Malaysia 1963 and New Malaysian 2018.

\section{References}

Bailey, F. G. (1969). Decisions by Consensus in Council and Committees with Special Reference to Village and Local Government in India. In. Political System and the Distribution of Power, pp. 1-20. Michael Banton (pnyt). London: Tavistock Publications.

Binningsbo, H. M. (2006). Power sharing and post-conflict period. Proposal Paper of PowerSharing and Democratic Governance in Divided Society Workshop, PRIO, 21 August 2006.

JPNIN. (2016). Retrieved from http://www.jpnin.gov.my/ms/kenegaraan/majlis-konsultasiperpaduan-negara-mkpn pada 21/11/16.

Faur, D. L. (2012). "From Big Government to Big Governance"? (Edt) Levi-Faur, D. In. Governance: UK: Oxford University Press.

Lijphart, A. (1977). Democracy in Plural Society. New Haven, Connecticut: Yale University Press.

Lijphart, A. (1999). Patterns of Democracy: Government Forms and Performance in Thirty-Six Countries. Yale University Press.

Noor, M. M. (2012). Kerencaman sosial dan penipisan batas etnik: kepelbagaian etnik dan perkongsian hidup bersama di Malaysia. Public Lecture for Professorship Universiti Kebangsaan Malaysia. Organised by Universiti Kebangsaan Malaysia. Bangi, 27 December 2012.

McAdam, D. (2011). Collective Action. In. The Concise Encyclopedia of Sociology, pp. 68-69. Ritzer, G \& Ryan, J. M (pnyt). UK: Blackwell Publishing Ltd.

Mohamed, N. (2018). Governan: Konsensus dan Pembinaan Perpaduan melalui Peranan Jawatankuasa Perhubungan Kaum (JPK) 1948. PhD Thesis. Universiti Kebangsaan Malaysia.

Risse, T. (pnyt). (2011). Governance in areas of limited statehood: Introduction and overview. In. Governance without a State? Policies and Politics in Areas of Limited Statehood. New York: Colombia University Press.

Hassan, S. A., \& Khairuldin, W. M. K. F. W. (2020). Research Design Based on Fatwa Making Process: An Exploratory Study. International Journal of Higher Education, 9(6), 241246. 
Said, N. A., \& Khairuldin. (2017). Freedom of Speech in Islam and its Connection with Street Demonstrations. International Journal of Academic Research in Business and Social Sciences, 7(4), 122-129.

Ibrahim, l., \& Khairuldin. (2017). Fatwa as a Medium Da'wah: Studies on the Role of Mufti as a Preacher. International Journal of Academic Research in Business and Social Sciences, 7(4), 10-18.

Rhodes, R. A. W. (1996). The New Governance: Governing without Government. Political Studies Association, xliv, 652-667. Cambridge: Blackwell Publisher.

Saravanamuttu, J. (2016). Power Sharing in a Divided Nation: Mediated Communalism and New Politics in Six Decades of Malaysian's Election. Singapura: ISEAS.

Faruqi, S. S. (2015). Race relations and the federal constitution. The Star Online, $3^{\text {rd }}$ September 2015.

Shamsul. (2018). Membina Tapak Integrasi Mengurus Kepelbagaian Masyarakat. Keynote Address by Profesor Datuk Dr. Shamsul di Seminar COSNA 6, at Universiti Sultan Zainal Abidin on 2 December 2018.

Steiner, J., \& Dorff, R. (1980). A theory of Political Decision Models: Intraparty Decision Making in Switzerland. Chapell Hill: University of North California Press.

Wan, A. H., \& Wan, P. M. (2008). Clinical Sociology and Community Mediation: Training Grassroots Leaders in Multiethnic Malaysian Communities. Fritz, J. M (Editor). In International Clinical Sociology. USA: Springer. Retrieved from https://books.google.com.my/books?isbn=0387738274 on 7 January 2018. 